\title{
Argumentation and fallacies in creationist writings against evolutionary theory
}

\author{
Petteri Nieminen ${ }^{1,2^{*}}$ and Anne-Mari Mustonen ${ }^{1}$
}

\begin{abstract}
Background: The creationist-evolutionist conflict is perhaps the most significant example of a debate about a well-supported scientific theory not readily accepted by the public.

Methods: We analyzed creationist texts according to type (young earth creationism, old earth creationism or intelligent design) and context (with or without discussion of "scientific" data).

Results: The analysis revealed numerous fallacies including the direct ad hominem-portraying evolutionists as racists, unreliable or gullible_-and the indirect ad hominem, where evolutionists are accused of breaking the rules of debate that they themselves have dictated. Poisoning the well fallacy stated that evolutionists would not consider supernatural explanations in any situation due to their pre-existing refusal of theism. Appeals to consequences and guilt by association linked evolutionary theory to atrocities, and slippery slopes to abortion, euthanasia and genocide. False dilemmas, hasty generalizations and straw man fallacies were also common. The prevalence of these fallacies was equal in young earth creationism and intelligent design/old earth creationism. The direct and indirect ad hominem were also prevalent in pro-evolutionary texts.

Conclusions: While the fallacious arguments are irrelevant when discussing evolutionary theory from the scientific point of view, they can be effective for the reception of creationist claims, especially if the audience has biases. Thus, the recognition of these fallacies and their dismissal as irrelevant should be accompanied by attempts to avoid counter-fallacies and by the recognition of the context, in which the fallacies are presented.
\end{abstract}

Keywords: Argumentation scheme; Creationism; Evolution; Fallacies; Intelligent design

\section{Background}

The antagonism between religion and natural sciences is often a reflection of perceived contradictions between scientific data and (personal) interpretation of religious texts, especially the Bible (McGrath 2010). The acceptance of biological evolution by the public varies being the highest in Iceland (84.9\%) and Denmark (82.2\%) and the lowest, e.g., in the United States (39.7\%) and Turkey (26.0\%) (Data360.org 2006; 34 countries sampled). The theory of evolution since Wallace (1858) and Darwin (1859) suggests that humans developed naturally over a very long period of time from other life forms. This is a challenge for some forms of religious faith that perceive

\footnotetext{
* Correspondence: petteri.nieminen@uef.fi

${ }^{1}$ Institute of Biomedicine/Anatomy, University of Eastern Finland, Faculty of Health Sciences, School of Medicine, P.O. Box 1627, FI-70211 Kuopio, Finland ${ }^{2}$ Philosophical Faculty, School of Theology, University of Eastern Finland, P.O. Box 111, Fl-80101 Joensuu, Finland
}

humans separate from other organisms and emphasize the literal interpretation of the Bible (Numbers 1982, McGrath 2010).

Traditionally, creationism has been classified into four principal types (Scott 1997, McGrath 2010). Young earth creationism (YEC) states that the earth was created 6000-8000 years ago and the flood of Noah occurred exactly as written in the Old Testament. Old earth creationism (OEC) interprets the six-day creation story symbolically to represent longer time periods to accommodate the geological age of the earth. Intelligent design (ID) requires supernatural intervention during the formation of basic body plans and biological molecules by trying to identify "irreducible complexity", i.e., structures that could not have evolved by natural processes only. Theistic evolution accepts biological evolution as a tool of a deity to produce the observed biodiversity (McGrath

\section{Springer}


2010) and, thus, it is "creationism" only in the broadest sense.

YEC, OEC and ID mostly share a common notion of "individually created kinds" (Hebrew מין [min], "kind"; e. g., Genesis 1:11-25, 6:19-20; King James Bible 2013). Creationists (especially YEC) consider variation and change possible within the "kinds"; however, any change of a "kind" into another or the appearance of new "kinds" requires supernatural intervention (ID). While there is disagreement on the classification of "kinds", YEC, OEC and ID state that the evolutionary concept of these taxa developing as a result of natural processes is false (McGrath 2010). The creationist "kind" is not the same as the taxonomical species but corresponds often closely to biological families (Numbers 2011).

Creationist writings attempt to disprove biological evolution (YEC, OEC and ID) and the age of the earth (YEC) by various strategies. One approach is to present selected data from natural sciences as counter-evidence against evolution, which has produced also numerous rebuttals from evolutionary proponents (Young 1985, Shermer 2002, Pennock 2003, Isaak 2006, Deming 2008,
Durrett and Schmidt 2008, Panda's Thumb 2013). These scientific rebuttals are not discussed in detail here. Creationist writings present also repeated arguments that are not directly connected to the scientific proof of evolution. We used argumentation-oriented textual analysis to unravel prevalent practices that dominate the creationist-evolutionist debate. We hypothesized that discursive practices not based on debating observational evidence per se would contain fallacious arguments that could eventually affect the reception of the creationist claims by their audience.

\section{Methods}

Creationist authors and publications were chosen for analysis based on their visibility and impact in social media (Table 1). To assess the potential significance of these English-language-derived creationist arguments locally, highly-cited Finnish creationist authors were also analyzed. We included a sample of rebuttals by evolutionary proponents to analyze if similar fallacies could be observed on both sides of the debate. The analysis proceeded as follows: we determined the position of the writer

Table 1 Sources of principal sample material

\begin{tabular}{|c|c|c|c|}
\hline Institution/Author & Format & Type & Source/Publisher \\
\hline Answers in Genesis & Online articles & YEC & http://www.answersingenesis.org/ \\
\hline \multirow[t]{2}{*}{ Creation Ministries International } & - Creation Magazine & YEC & http://creation.com/ \\
\hline & - Journal of Creation & & \\
\hline \multirow[t]{2}{*}{ Creation Research Society } & - Creation Matters & YEC & http://www.creationresearch.org/index. \\
\hline & - CRS Quarterly & & \\
\hline Institute for Creation Research & Online articles & YEC & http://www.icr.org/ \\
\hline $\begin{array}{l}\text { Intelligent Design and Evolution Awareness } \\
\text { (IDEA) Center }\end{array}$ & Online articles & ID/OEC & http://www.ideacenter.org/ \\
\hline Intelligent Design network & Online articles & ID & $\begin{array}{l}\text { http://www.intelligentdesignnetwork. } \\
\text { org/index.htm }\end{array}$ \\
\hline UK Apologetics & Online articles & YEC & http://www.ukapologetics.net/ \\
\hline Behe, MJ & $\begin{array}{l}\text { The edge of evolution. The search for the limits of } \\
\text { Darwinism (2007) }\end{array}$ & ID & Free Press \\
\hline \multirow[t]{2}{*}{ Johnson, PE } & - Darwin on trial (1993) & ID/OEC & http://www.talebooks.com \\
\hline & - Reason in the balance (1995) & & InterVarsity Press \\
\hline \multirow[t]{2}{*}{ Puolimatka, T (in Finnish) } & • Faith, science and evolution (2009) & ID/OEC & Uusi Tie \\
\hline & - A test for openness in science discussion (2010) & & \\
\hline \multirow[t]{3}{*}{ Reinikainen, P (in Finnish) } & - The forgotten Genesis (1991) & YEC & Uusi Tie \\
\hline & - The enigma of the dinosaurs and the Bible (2003) & & Kuva ja Sana \\
\hline & - Darwin or intelligent design (2011) & & Uusi Tie \\
\hline Davis, $\mathrm{P}$, and Kenyon, DH & $\begin{array}{l}\text { Of pandas and people. The central question of } \\
\text { biological origins (1998) }\end{array}$ & ID & Haughton \\
\hline Morris, HM & The remarkable birth of planet earth (1972) & YEC & Bethany Fellowship \\
\hline TalkOrigins archive (many authors) & Online articles & ET & http://www.talkorigins.org/ \\
\hline Panda's Thumb (many authors) & Online articles & ET & http://www.pandasthumb.org/ \\
\hline Young, W & Fallacies of creationism (1985) & ET & Detselig Enterprises \\
\hline
\end{tabular}

$\mathrm{YEC}=$ young earth creationism, $\mathrm{OEC}=$ old earth creationism, ID = intelligent design, $\mathrm{ET}$ = proponents of evolutionary theory. 
in the creationism-evolution conflict (pro-creationism, anti-creationism). The creationist texts were classified as YEC, OEC or ID, but there was a lot of overlap between OEC and ID, which is indicated by ID/OEC. We excluded theistic evolution, as it basically accepts biological evolution (International Theological Commission 2004). The arguments were analyzed and classified according to argumentation theory with methods employed previously (Sahlane 2012). We also inspected the arguments according to the context of proving or disproving theories within natural sciences, i.e., we documented if the texts, books, journal issues or Internet sites that contained fallacious arguments also discussed the "scientific evidence" for creationism.

The relevance of the arguments as proof for or against evolution was based on the methodology of biological research. Very briefly, the process includes $i$ ) observations (such as the fossil record) and experimental data (e.g., DNA sequences). $i$ i) The data are analyzed and interpreted based on existing knowledge and finally iii) the hypotheses are tested, auxiliary hypotheses, negative and zero findings considered and the manuscript is submitted to review, $i v$ ) scrutinized and rejected or published. The method also $v$ ) requires the data to be reproducible. Thus, evidence and not, e.g., personal characteristics of scientists, determines the validity of a theory. We assessed the fallacies against this background and discussed the findings with alternative hypotheses, i.e., if there are cases where the arguments would be valid and not fallacious in the context of disproving/proving evolution.

Fallacies are "violations of rules for critical discussion" that undermine the efforts to reach a rational outcome of a controversial issue (van Eemeren and Grootendorst 1992). Fogelin and Duggan (1987) argue further that fallacies are not simply "invalid argumentation". They can also be regarded as "...a general term for criticizing any general procedure used for the fixation of beliefs that has an unacceptably high tendency to generate false or unfounded beliefs". The present study does not aim to assess if the claims presented by creationists are "true" or "false" but evaluates if some of the repeating arguments used to validate creationism are improper in scientific context and can be disregarded as proofs against evolution. Fallacies were classified according to the scheme in Table 2 .

To assess the prevalence of the analyzed fallacies in the sample material, the presence of a particular fallacy in a single article, book or online text was listed. However, the TalkOrigins archive's general homepage was excluded as it is mostly an index and does not contain text per se. Multiple occurrences were not recorded due to the vast differences in text length. The distribution of the fallacies between YEC, ID/OEC and pro-evolutionary texts was analyzed with the $X^{2}$-test or, in case the test criteria were not met, with the Fisher's exact test (SPSS $v 19$ software package, IBM, Armonk, NY, USA). The results are presented as percentage of texts within category (YEC, ID/ OEC or pro-evolutionary) that contained the fallacy. The $p$ value $<0.05$ was considered statistically significant.

\section{Results \\ Ad hominem fallacies}

The direct ad hominem attempts to disqualify the opponent's legitimacy in the issue (van Eemeren and Grootendorst 1992, Sahlane 2012). In creationist writings, ad hominem fallacies display Darwin as racist, sadist, psychotic and dishonest (Bergman 2004, 2005, Brace 2004, 2006; Table 3). There are also ex silentio arguments accusing him indirectly of racism and genocide: "(He) failed to condemn the destruction of primitive races” (Puolimatka 2009). An oft-repeated argument concerns Haeckel, who is considered a racist and criticized for forgery in his embryological drawings (Reinikainen 2003, Luskin 2009, Puolimatka 2009, 2010). More recent proponents of evolutionary theory can be referred to as "the premier atheistic populist propagandist for evolution" (Brace 2004) or as "a Marxist atheist" (Reinikainen 2011).

Another form of direct ad hominem suspects the evolutionists' qualifications or integrity (Table 3) by stating, for instance, that "Darwin himself was not a scientist... he was a one-time preacher of the gospel who went astray..." and "Darwin heavily plagiarized his theory... and many believe that he seized upon a chance to acquire fame and security at least partially from the work of others" (Brace 2004). Direct ad hominem occurs also when scientists, whose words have been previously cited as supporting creationism, have published more recent texts taking the opposite view. For example, there is the well-known statement by Popper on the concept of natural selection not being scientific (Johnson 1993, Puolimatka 2009), which he later reformulated (Popper 1978). The change of opinion is attacked by stating that "[Popper] was besieged by indignant Darwinist protests" (Johnson 1993, Puolimatka 2009). Likewise, there is a creationist report citing a scientific paper about the alleged discovery of "dinosaur blood" (Wieland 1997). When an author of the original report (Schweitzer et al. 1997) refuted the YEC claim, she was criticized for "being under a lot of pressure and, of course, has tried to wriggle out of these observations... to preserve her credibility in the scientific community" (Reinikainen 2003).

In the sampled creationist writings, the indirect ad hominem ( $t u$ quoque) occurs most often in two forms (Table 3). The first type accuses evolutionary proponents of using arguments that they themselves condemn when used by creationists. Typically, creationists criticize evolutionists of introducing religious arguments while demanding that religion should not be allowed to enter 
Table 2 Definitions and general examples of commonly occurring argumentative fallacies in creationist writings

\begin{tabular}{|c|c|c|c|}
\hline & Definition & Reference(s) & Example(s) \\
\hline Ad hominem & Attacking an opponent's character instead of evidence. & $\begin{array}{l}\text { Van Eemeren and } \\
\text { Grootendorst } \\
\text { 1992, Yap } 2013\end{array}$ & $\begin{array}{l}\text { Evolutionists portrayed, for example, as racist, } \\
\text { sadist, psychotic or plagiarist. }\end{array}$ \\
\hline $\begin{array}{l}\text { Circumstantial } \\
\text { ad hominem } \\
\text { (= tu quoque) }\end{array}$ & $\begin{array}{l}\text { Instead of evidence, an opponent's past actions, words } \\
\text { or motives are put under suspicion. }\end{array}$ & Sahlane 2012 & $\begin{array}{l}\text { Scientists "admitting" lack of evidence for } \\
\text { evolution, such as transitional fossils. }\end{array}$ \\
\hline Poisoning the well & $\begin{array}{l}\text { Claiming that the opponent cannot help being } \\
\text { opposed to an argument and, thus, the opponent } \\
\text { can be discounted in advance. }\end{array}$ & Walton 2006 & $\begin{array}{l}\text { Claims of the type: "Evolutionists refuse to } \\
\text { consider supernatural explanations". }\end{array}$ \\
\hline $\begin{array}{l}\text { Appeal to authority } \\
\text { and ad populum }\end{array}$ & $\begin{array}{l}\text { The argument is right because an authority } \\
\text { (or majority) says it is right. }\end{array}$ & Jovičić 2004 & $\begin{array}{l}\text { Historical and contemporary scientists quoted as } \\
\text { believing in creation. Out-of-context citations } \\
\text { of scientists "doubting" evolution. Referrals to } \\
\text { majority of citizens believing in creation. }\end{array}$ \\
\hline $\begin{array}{l}\text { Appeal to } \\
\text { consequences and } \\
\text { guilt by association }\end{array}$ & $\begin{array}{l}\text { Instead of evidence, a theory is rejected based on its } \\
\text { alleged consequences or linking the opponent's } \\
\text { viewpoint to distasteful and evil phenomena. }\end{array}$ & $\begin{array}{l}\text { Van Eemeren and } \\
\text { Grootendorst } \\
\text { 1992, Curtis } 2001\end{array}$ & $\begin{array}{l}\text { Evolutionary theory associated to, for instance, } \\
\text { Nazism, abortions, adultery and eugenics. }\end{array}$ \\
\hline Slippery slope & $\begin{array}{l}\text { Appealing to an undesirable sequence of events in } \\
\text { order to oppose an argument. }\end{array}$ & $\begin{array}{l}\text { Van Eemeren and } \\
\text { Grootendorst } 1992\end{array}$ & $\begin{array}{l}\text { Evolutionary theory allegedly triggers a chain of } \\
\text { events from, e.g., racism and eugenics to mass } \\
\text { murder. }\end{array}$ \\
\hline Straw man & $\begin{array}{l}\text { The opponent distorts the arguments attacking the } \\
\text { distortion. }\end{array}$ & $\begin{array}{l}\text { Aikin and Casey } \\
2011\end{array}$ & $\begin{array}{l}\text { Overemphasizing aspects of "chance" in } \\
\text { evolution. }\end{array}$ \\
\hline False dilemma & $\begin{array}{l}\text { A complex case is simplified into too few choices and } \\
\text { a choice made among this shortened menu. }\end{array}$ & $\begin{array}{l}\text { Curtis 2001, } \\
\text { Dowden 2010, } \\
\text { Tomić } 2013\end{array}$ & $\begin{array}{l}\text { Creation is the "only alternative" to alleged } \\
\text { problems of evolutionary theory. }\end{array}$ \\
\hline $\begin{array}{l}\text { Hasty } \\
\text { generalization }\end{array}$ & $\begin{array}{l}\text { Conclusions are based on limited evidence and/or } \\
\text { some evidence is suppressed. }\end{array}$ & Walton 1999a & $\begin{array}{l}\text { One problem with a scientific method causes } \\
\text { the whole concept of evolution to collapse } \\
\text { (e.g., regarding radiometric dating). }\end{array}$ \\
\hline $\begin{array}{l}\text { Argument from } \\
\text { incredulity and } \\
\text { ad ignorantiam }\end{array}$ & $\begin{array}{l}\text { Attacking a proposition based on lack of definite } \\
\text { evidence; accusing a theory of being irrational without } \\
\text { presenting actual evidence. }\end{array}$ & $\begin{array}{l}\text { Dawkins 1986, } \\
\text { Walton 1999b, } \\
\text { Curtis } 2001\end{array}$ & $\begin{array}{l}\text { "It is hard to imagine that [an aspect of } \\
\text { evolutionary theory] would be true." }\end{array}$ \\
\hline Equivocation & Misusing words in an ambiguous manner. & $\begin{array}{l}\text { Van Eemeren and } \\
\text { Grootendorst } 1992\end{array}$ & $\begin{array}{l}\text { E.g., evolutionary theory } \approx \text { Darwinism } \approx \text { social } \\
\text { Darwinism. }\end{array}$ \\
\hline $\begin{array}{l}\text { Appeal to fear and } \\
\text { force }\end{array}$ & $\begin{array}{l}\text { Instead of discussing evidence, the opponent is } \\
\text { threatened with sanctions. }\end{array}$ & $\begin{array}{l}\text { Van Eemeren and } \\
\text { Grootendorst } \\
\text { 1992, Woods } 1998\end{array}$ & $\begin{array}{l}\text { Disbelief in literal Genesis (i.e., acceptance of } \\
\text { biological evolution) leads to "grave } \\
\text { consequences". }\end{array}$ \\
\hline $\begin{array}{l}\text { Appeal to pity or } \\
\text { ridicule }\end{array}$ & $\begin{array}{l}\text { Emotional appeal instead of presenting actual } \\
\text { evidence. }\end{array}$ & Curtis 2001 & $\begin{array}{l}\text { "Supporters of creationism are discriminated by } \\
\text { evolutionists." }\end{array}$ \\
\hline
\end{tabular}

scientific discussions (Johnson 1993, Puolimatka 2009). The second type deals with quotes of evolutionary proponents allegedly affirming, for instance, that the fossil record would be seriously deficient. These citations can also be considered quote mining, out-of-context citations used to promote an argument (Young 1985, Pieret 2006). Opinions of scientists can obviously be based on research but proof does not depend on the person but only on the actual evidence itself. In the above cases, the arguments also approach the two wrongs make a right fallacy, where a potentially wrong action (introducing religion into natural sciences by a creationist) is defended by pointing to similar actions by those of the opposite opinion.

In creationist texts, the poisoning the well fallacy often takes the form of indicating evolutionary proponents as having too strong naturalistic biases, which prevent them from considering supernatural hypotheses (Harris and Calvert 2003). This is clearly formulated by Puolimatka
(2009): "When discussing with dogmatic naturalists it can be futile to raise the question about the truth of evolutionary theory, because from their religious [naturalism taken as religion] viewpoint this question cannot be even posed in a meaningful manner" and "The atheist or agnostic approaches are the only alternatives accepted in the discussion".

\section{Appeals to authority}

Appeals to authority are fallacies, where the claim is presented as right because an expert or an authoritative power says it is right (van Eemeren and Grootendorst 1992). In the sample material, the authoritativity of the authors referred to is often augmented by including their merits and (religious) affiliations when cited. For example, criticism for naturalistic abiogenesis is accompanied by stating that an influential critic of the theory ("cells cannot be born out of inorganic substance in reality or in theory") 
Table 3 Examples of ad hominem arguments in creationist writings

\begin{tabular}{|c|c|c|c|c|}
\hline Type & Portrayal or citation & Type & Science content & Source \\
\hline \multirow[t]{2}{*}{ Demonization } & $\begin{array}{l}\text { "One side of Darwin rarely discussed in popular and scientific literature was } \\
\text { his powerful sadistic bent." }\end{array}$ & YEC & No & Bergman 2005 \\
\hline & $\begin{array}{l}\text { "...the editors and defenders of Darwin have done a superb job in hiding } \\
\text { Darwin's clear racism..." }\end{array}$ & YEC & Yes & Brace 2006 \\
\hline \multirow[t]{3}{*}{ Disqualification } & $\begin{array}{l}\text { "....although evolutionists continue to demolish one another's hypotheses, } \\
\text { they fail to come to terms with the underlying problem of their fossil } \\
\text { investigations - the materialist worldview." }\end{array}$ & YEC & Yes & Doyle 2007 \\
\hline & "Was Charles Darwin psychotic? A study of his mental health" & YEC & Yes & Bergman 2004 \\
\hline & $\begin{array}{l}\text { "Anyone who has not studied inorganic chemistry and biochemistry at } \\
\text { university level, should not take stand on the concept of chemical } \\
\text { evolution, i.e., emergence of the first cell." }\end{array}$ & YEC & Yes & Reinikainen 2013b \\
\hline \multirow[t]{3}{*}{ Dishonesty } & $\begin{array}{l}\text { (Darwin was absent from a public debate) "... is there just a suspicion of } \\
\text { cowardice tinged with guilt here?" }\end{array}$ & YEC & Yes & Brace 2006 \\
\hline & $\begin{array}{l}\text { Punctuated equilibrium models described as an ad hoc escape from lack } \\
\text { of evidence on evolutionary theory. }\end{array}$ & ID/OEC & Yes & $\begin{array}{l}\text { Johnson 1993, 44; } \\
\text { Puolimatka 2009, 421; } \\
\text { Puolimatka 2010, } 381\end{array}$ \\
\hline & $\begin{array}{l}\text { "...if evolutionists really believe what they say or if they are purposively } \\
\text { trying to mislead. I suspect there are some of both." }\end{array}$ & YEC & Yes & Morris 2013 \\
\hline Gullibility & $\begin{array}{l}\text { "...most evolutionists are evolutionists because they are victims of the } \\
\text { wrong teaching of others." }\end{array}$ & YEC & Yes & Morris 2013 \\
\hline \multirow[t]{3}{*}{$\begin{array}{l}\text { Circumstantial } \\
\text { ad hominem }\end{array}$} & $\begin{array}{l}\text { "Most evolutionists... will freely admit that there are no 'missing links' } \\
\text { although there have been several missing link hoaxes!" }\end{array}$ & YEC & Yes & Brace 2004 \\
\hline & $\begin{array}{l}\text { Naturalists are accused of discussing religion although they claim that } \\
\text { religion should be left out of scientific discussions. }\end{array}$ & ID/OEC & Yes & Puolimatka 2009, 235-271 \\
\hline & $\begin{array}{l}\text { Citations of evolutionary biologists allegedly affirming the lack of evidence } \\
\text { for evolution. }\end{array}$ & ID/OEC & Yes & $\begin{array}{l}\text { Davis and Kenyon 1998, 23; } \\
\text { Puolimatka 2009, 419-422; } \\
\text { Puolimatka 2010, 366-384 }\end{array}$ \\
\hline
\end{tabular}

$\mathrm{YEC}=$ young earth creationism, OEC = old earth creationism, ID = intelligent design. "Science content" signifies whether the arguments are presented in the context of debate about the scientific details of evolutionary theory.

is "an atheistic Nobel-prize winner" (Reinikainen 2011). Thus, it is implicated that even atheists agree with creationists. Historically authoritative figures of natural sciences (e.g., Newton, Maxwell, Linné) are also introduced to give testimonials of their Christian faith (Reinikainen 1991, Puolimatka 2009). Appeals to authorities can also occur as out-of-context citations of scientists allegedly stating that there would be serious flaws with evolutionary theory (ibid.). Also influential "converts into theism" are presented, for example, the "former atheist" Antony Flew who converted "to theism" (in reality, into some kind of deism; Carrier 2004) after having encountered alleged problems in evolutionary theory (Reinikainen 2011).

Creationists often appeal to numerous unknown authorities who oppose evolutionary theory. This takes the form of "large and/or growing numbers of scientists who doubt or renounce evolutionary theory" (Morris 1972, Davis and Kenyon 1998, Luskin and Gage 2008, Puolimatka 2009, Reinikainen 2011). These are also ad populum fallacies, where "the claim is supposed to be right because everybody thinks it is right" (van Eemeren and Grootendorst 1992). In these cases, the proportion of a population, e.g., U.S. citizens, that believes in special creation or divine guidance of evolution (82-87\%) is introduced when justifying teaching ID to pupils (Harris and Calvert 2003). Obviously, the validity of a theory does not depend on the number of its followers.

\section{Appeals to consequences, guilt by association, slippery slopes and straw men}

Appeals to consequences typically link evolutionary theory to renouncement of theism, which would inevitably lead to immorality (Morris 1972) thus denying moral autonomy (Mackie 1982, Brink 2007; Table 4). For instance, creationists can claim that naturalist Darwinism "provides a viewpoint, which takes the mass destruction of living creatures as a positive endpoint" (Puolimatka 2010). Guilt by association fallacy links the opposing viewpoint to phenomena or groups deemed unreliable or evil without concentrating on the actual evidence (Curtis 2001). Numerous examples link evolutionary theory to the Holocaust or other historical events. Creationists (Johnson 1995, Puolimatka 2009, Grigg 2010) also associate the acceptance of evolutionary theory to the screening of fetal disorders and mistreatment of disabled people. Examples also include connecting evolutionary theory to 
Table 4 Examples of ad consequentiam and guilt by association arguments in creationist writings

\begin{tabular}{|c|c|c|c|}
\hline Portrayal or citation & Type & Science content & Source \\
\hline "If Darwinism is true, Hitler was our savior and we have crucified him." & YEC & Yes & Bergman 1999 \\
\hline $\begin{array}{l}\text { "...the killing of so many millions of people, let alone the onslaught on defenceless unborn babies... } \\
\text { such action is totally consistent with evolutionary teaching." }\end{array}$ & YEC & Yes & Grigg 2005 \\
\hline $\begin{array}{l}\text { "The core idea of Darwinism is selection. The Nazis believed that they must direct the process of } \\
\text { selection to advance the German race." }\end{array}$ & YEC & $\mathrm{No}^{1}$ & Grigg 2005 \\
\hline $\begin{array}{l}\text { "Science, divested of the moral compass of biblical Christianity, played a significant role in } \\
\text { establishing the political and social conditions in Germany that led to the horrors of Nazism." }\end{array}$ & YEC & $\mathrm{No}^{1}$ & Harker 2011 \\
\hline $\begin{array}{l}\text { "...if life is an accident (Darwinist worldview)... why not make human clones? Why not abort } \\
\text { unwanted children? Why not euthanize the 'useless' aged?... Why not 'steal, kill, and destroy'?" }\end{array}$ & ID & Yes & $\begin{array}{l}\text { Harris and Calvert } \\
2003\end{array}$ \\
\hline $\begin{array}{l}\text { "Modern racism has always found its strongest and most vicious expression among doctrinaire } \\
\text { evolutionists—-men such as Karl Marx, Adolf Hitler..." }\end{array}$ & YEC & Yes & Morris 1972 \\
\hline "Genocide, of course, is merely a shocking name for the process of natural selection..." & ID & Yes & $\begin{array}{l}\text { Johnson 1995, } \\
144\end{array}$ \\
\hline $\begin{array}{l}\text { "Evolutionary theory was applied into practice by Stalin and it caused the loss of tens of millions } \\
\text { of lives." }\end{array}$ & YEC & Yes & $\begin{array}{l}\text { Reinikainen 1991, } \\
10\end{array}$ \\
\hline $\begin{array}{l}\text { Darwinism associated to Stalinism and Lysenkoism² , social Darwinism, eugenics, Nazism, immorality, } \\
\text { abortions and euthanasia. }\end{array}$ & ID/OEC & Yes & $\begin{array}{l}\text { Puolimatka 2010, } \\
151-201,462-477\end{array}$ \\
\hline
\end{tabular}

$\mathrm{YEC}=$ young earth creationism, $\mathrm{OEC}=$ old earth creationism, ID = intelligent design. "Science content" signifies whether the arguments are presented in the context of debate about the scientific details of evolutionary theory.

${ }^{1}$ Citations are from articles of the journals "Creation" and "Journal of Creation". While the articles per se do not contain scientific issues, creationist interpretations of scientific data are presented as proofs for creation in the same issues. ${ }^{2}$ It is very problematic to use Lysenkoism as a branch of "Darwinism" as, contrary to evolutionary theory of the era, Lysenko believed in the heritability of acquired characteristics, which was encouraged by communist indoctrination (Dawkins 1986, 292).

mass murders in welfare states (Hodge 2007, Puolimatka 2010, Bergman 2012).

Brace (2006), Puolimatka (2009) and Bergman (2012) have also claimed that the general acceptance of evolutionary theory would initiate a chain of events "going from bad to worse" including eugenics, discrimination and violation of human rights, forced sterilization and genocide. This is the slippery slope fallacy (van Eemeren and Grootendorst 1992; Table 5). For the slippery slope argument not to be fallacious, the disclaimer should be able to present logical causal relationships between the consecutive steps to the outcome. However, in the case of disproving evolutionary theory, this would not be sufficient, as the validity of a theory in the natural sciences is determined by evidence and not by its alleged applications. Even when the creationist writers do not directly claim that the slippery slope (or ad consequentiam) arguments disprove evolution, the association is present and, as hypothesized by Yap (2013), these arguments can be very effective for those observing the evolutioncreationism debate.

Creationist straw man fallacies commonly deal with simplifications of evolutionary theory, such as overemphasis on random mutations or misunderstanding transitory forms, molecular differences between taxa and the origin of the universe ("...according to evolutionists a hydrogen atom formed by the Big Bang created the whole universe and life"; Reinikainen 2011). We do not discuss these fallacies in detail here as they have been refuted on numerous occasions (e.g., Young 1985, Isaak 2006).

\section{False dilemma and hasty generalization}

In creationist texts it is usual to assume that there are only two choices: "There are only two alternatives: either

Table 5 Examples of slippery slope arguments in creationist writings

\begin{tabular}{|c|c|c|c|}
\hline Citation & Type & Science content & Source \\
\hline $\begin{array}{l}\text { "... rejection of the biblical record, especially the doctrine that all humans descended from the first man } \\
\text { and woman, Adam and Eve, leads to Darwinism, and evolution leads to racism and eugenics." }\end{array}$ & YEC & Yes & Bergman 2012 \\
\hline $\begin{array}{l}\text { "(Darwinism) directly led to the rise of Eugenics... Eugenics has been used as a justification of coercive } \\
\text { state-sponsored discrimination and human rights violations, such as forced sterilization of persons with } \\
\text { genetic defects, the killing of the institutionalized and, in some cases, genocide..." }\end{array}$ & YEC & Yes & Brace 2006 \\
\hline $\begin{array}{l}\text { "The extension of the Darwinist theory into morality can lead to morally questionable consequences, } \\
\text { such as fetal diagnostics aiming to eliminate the handicapped, abandoning handicapped people, or } \\
\text { even to genocide 'as a part of the realization of natural selection'." }\end{array}$ & ID/OEC & Yes & $\begin{array}{l}\text { Puolimatka } \\
2009,477\end{array}$ \\
\hline
\end{tabular}

YEC = young earth creationism, OEC = old earth creationism, ID = intelligent design. "Science content" signifies whether the arguments are presented in the context of debate about the scientific details of evolutionary theory. 
the world receives its order from an outside source or the order is innate without any order given from the outside" (Leisola 2012; Table 6). This false dilemma appears also when considering unresolved issues in evolution or abiogenesis ("The RNA world did not resolve this problem. Thus, only creation is left as an option"; Reinikainen 2011) or when discussing the potential moral dimensions of evolutionary theory. Obviously, the RNA world is not the only possible explanation to abiogenesis (e.g., Gilbert 1986, TalkOrigins archive 2013a) and there are several rational arguments presented for the autonomy of morality (Brink 2007).

Hasty generalization involves making conclusions that are based on limited sources or evidence (Walton 1999a). Creationists can claim that a single piece of data would be sufficient to disprove the whole theory of evolution. Reinikainen (2013a) writes that "this finding ['unfossilized' Tyrannosaurus rex bone] is a deathly blow to evolutionary theory". Hasty generalization is also present when extrapolating the results of one study after creationist re-interpretation. For example, Carter (2010) cites Hughes et al. (2010), who state that the difference between selected human and chimpanzee Y chromosome DNA sequences is $30 \%$. Creationists generalize this to be the case also in other parts of the genome. Carter (2010) continues: "...we now know that the old 'humans and chimps are 99\% identical' canard is passé", although the writers of the original paper make note of the fact that the other parts of the genome show 98\% similarity. There are also instances of generalization, when alleged isolated problems with evolutionary theory or related disciplines are considered adequate to disprove the theory in its entirety. An example of this is the creationist approach to radiometric dating: any alleged inaccuracy is seen as a refutation of the whole radiodating method (Swenson 2001), while geologists point to the overwhelming amount of evidence based on various radiometric procedures and their comparison to other methods indicating to the ancient age of the earth (Wiens 2002).

\section{Other creationist fallacies}

Utilizing the appeal to ignorance, creationists refer to unresolved questions as proofs of fatal weaknesses in evolutionary theory or as indications that the theory is about to collapse (Morris 1972, Johnson 1993, Reinikainen 2003, Behe 2007, Puolimatka 2009, Reinikainen 2011). For instance, Behe (2007) claims that there would be "a total lack of serious Darwinian explanations" regarding cilia. A form of the argument from ignorance is the argument from incredulity (Dawkins 1986), in which an author simply states that a theory is inconceivable or irrational. In the sample material, there are frequent appearances of this fallacy (e.g., Morris 1972). Some examples are as follows: "There is not even one reasonable suggestion on how life could have emerged from inorganic matter" and "...it is hard to imagine that chance and natural selection could explain the emergence of these types of systems" (Puolimatka 2009).

Sometimes the supposed lack of evidence becomes a statement with no references in a repeated ad nauseam pattern, e.g., when discussing the alleged lack of transitional fossils in the form of "no transitional forms have been found in the fossil record" (Puolimatka 2009). The same appears in Yahya (2006), who states repeatedly (16 occasions) based on similarities between fossils and modern species that living beings "did not evolve, but were created". Many of the claims presented and refuted in the early 1970's are also continuously repeated (often without citations) ad nauseam in later creationist texts. For instance, the arguments connecting Darwinism to atrocities have re-appeared for decades (Morris 1972, Bergman 1999, Brace 2004, 2006, Puolimatka 2010, Reinikainen 2011).

Equivocation misuses words in a manner that creates ambiguousness (van Eemeren and Grootendorst 1992). In the sample material, it is common to link "social

Table 6 Examples of false dilemmas in creationist writings

\begin{tabular}{|c|c|c|c|}
\hline Portrayal or citation & Type & Science content & Source \\
\hline $\begin{array}{l}\text { "If the biblical narrative on the origin of man as a living soul created in the image of God is not } \\
\text { true, the whole Bible and Christianity lose their significance." }\end{array}$ & YEC & Yes & Reinikainen 2013b \\
\hline $\begin{array}{l}\text { "The idea of pure chance... must be sheltered from all criticism. All other alternatives are } \\
\text { unthinkable... The central and unique position of idea of pure chance cannot be questioned in } \\
\text { the atheist framework... The atheist or materialistic approach tries to reduce the whole reality into } \\
\text { its physical parts and pure chance. The theist builds his scientific explanation on the assumption } \\
\text { that the order of the universe basically originates from God." }\end{array}$ & ID/OEC & Yes & $\begin{array}{l}\text { Puolimatka 2010, } \\
272\end{array}$ \\
\hline $\begin{array}{l}\text { "If people are created in the image of God, they have to be treated accordingly... If there is no } \\
\text { creator, everybody is free to do whatever he feels according to his own discretion." }\end{array}$ & YEC & Yes & Reinikainen 1991, 56 \\
\hline $\begin{array}{l}\text { For the atheist, evolutionary theory is the only possible explanation and the only alternative is that } \\
\text { the world was created by God. }\end{array}$ & ID/OEC & Yes & $\begin{array}{l}\text { Puolimatka 2009, } \\
142-143,157\end{array}$ \\
\hline
\end{tabular}

$\mathrm{YEC}=$ young earth creationism, OEC = old earth creationism, ID = intelligent design. "Science content" signifies whether the arguments are presented in the context of debate about the scientific details of evolutionary theory. 
Darwinism" to evolutionary theory (Bergman 1999, Puolimatka 2010, Bergman 2012). Another example is the use of the word "selfish" in the concept "selfish gene" (Dawkins 1989a). While creationist authors may acknowledge that evolutionists do not necessarily use the word "selfish" in its everyday meaning, they still claim that evolutionists are saying that genes are "ruthlessly immoral" and that genes "created us, our bodies and our minds" and add an ad ridiculum comment: "a collection of chemicals would hardly be experiencing any vain self-satisfaction from merely being able to copy themselves" (Puolimatka 2009). In addition to direct equivocations, there are also conceptual equivocations: creationists interpret concepts differently from scientists. Boudry et al. (2010b) have pointed to equivocation in the concept "information" in ID, with its scientific interpretation of "a measure of randomness" being replaced by its colloquial use of "meaningful message" thus making it more persuasive to refer to DNA sequences as "designed".

We present here two other conceptual equivocations in the sampled texts. The first one deals with the confusion of transitional forms and fossils. It occurs when creationists present genetic comparisons as evidence against evolution. They acknowledge that the differences in percentage between the DNA sequences of different life forms compared to humans form a sequence, in which mammals are the most similar followed by reptiles, amphibians, fish, various invertebrates, fungi, plants and prokaryotes. However, when creationists subsequently compare the sequences to prokaryotes, they notice that all the other life forms differ from bacteria by the same percentage. They surmise this to be counter-evidence against evolution (Reinikainen 1991, Johnson 1993, Davis and Kenyon 1998). Creationists claim that, as amphibians are supposedly half-way between bacteria and humans, their genes should also be more similar to bacteria than those of humans. Here the concepts of transitional forms and ancestors are confused with the descendants of these ancestors. Actually, comparisons from the human point of view reflect the time that has passed since our common ancestor with the abovementioned life-forms lived. Thus, our last common ancestor with other mammals is more recent than that of mammals and fish (Purves et al. 2006), as observed in the sequences. But from the point of view of bacteria, the last common ancestor with humans, fish, invertebrates and plants is the same and all these other forms have had exactly the same time to develop since these taxa branched off from that of prokaryotes. Thus, creationists equivocate, e.g., ancestral amphibians with modern amphibians and ancestral transitional forms with the inexistent "modern transitional forms".

The second case of conceptual equivocation appears when creationists discuss statements of evolutionary biologists that are outside the scope of actual science. For instance, they can interpret an opinion or a popularized rebuttal of an evolutionist as evolutionary science per se and utilize these texts as evidence for evolution being the only allowed doctrine in the scientific community. An example is the appeal to a biologist "S.C. Todd", who refuted any possibility of considering supernatural explanations in the "scientific paper Nature" ("Even if all the data point to an intelligent designer, such a hypothesis is excluded from science because it is not naturalistic", cited by, e.g., Morris 2001 and Puolimatka 2009, see the actual text in Todd 1999). The original text was published as "Correspondence" and not as a peer-reviewed scientific paper.

The no true Scotsman fallacy (Dowden 2010) occurs as a device to redirect accusations from creationists when the discussion has reached a state of repeated $t u$ quoque arguments, such as in a debate on the "Darwinist" or "Christian" roots of Nazism. Creationists eliminate any possibility of them taking part in atrocities by stating that in case religious people are involved in violence, they are not "true" Christians. "We have often demonstrated that the occasional atrocities committed by professing Christians were completely contrary to the teachings of Christ, while the atrocities of $20^{\text {th }}$ century Nazis and Communists were totally consistent with evolutionary teaching (original emphasis)" (Sarfati 2007). In the same way, a scientist refuted the use of her findings to promote YEC and identified herself as "an evangelical Christian". This has been denounced by stating that she would not be a "true" evangelical: "[The scientist's] attitude to Scripture actually reflects a liberal, rather than evangelical approach to the Bible" (Catchpoole and Sarfati 2006).

Appeal to fear or force (ad baculum) threatens the other party with sanctions (van Eemeren and Grootendorst 1992, Woods 1998). Direct threats are relatively rare in the sample material, but the above-mentioned association of evolutionary theory to atrocities can also be seen as an appeal to fear. While the sampled texts do not directly threaten those who accept evolution with supernatural punishment, the authors associate the loss of faith in the literal interpretation of Biblical creation and its substitution with evolution with damnation. "There is a clear connection between creation and... the resurrection of the believers" (Reinikainen 1991). Ad baculum appears also when discussing the alleged fate of creationist or theistic scientists, if they publish material against evolution. "Those believing in creation are forced to silence in fear of losing their jobs or positions" (Reinikainen 2011). There are repeated anecdotal stories of mistreated creationist scientists unable to publish or forced to resign because of their opinions (Harris and Calvert 2003, Puolimatka 2009, 2010). These instances could also be classified as appeals to pity (ad misericordiam). The 
validity of the examples could, of course, be verified or disproved and there could exist a bias among scientists to prevent YEC and ID/OEC from being published. In the context of evolutionary science, these stories are basically irrelevant, but in the context of potential preexisting biases in the creationist-evolutionist debate, these arguments would not necessarily be fallacious.

\section{Fallacies in pro-evolutionary texts}

Direct ad hominem attacks by evolutionary proponents on creationists are quite similar to the fallacious arguments of creationists (Table 7). Perhaps the most notorious one states that "It is absolutely safe to say that if you meet somebody who claims not to believe in evolution, that person is ignorant, stupid or insane..." (Dawkins 1989b). Furthermore, evolutionists have stated in response to accusations of Darwin's racism that "Price, who is to young-earth creationism what Darwin is to evolution, was much more racist than Darwin" (TalkOrigins archive 2013b). Other personal attacks include characterization, such as "deplorable deceiver" (Buchanan 2010) or "Their lack of integrity may well drive any educated person away from consideration of the truth-claims of Jesus Christ" (Buchanan 2012).
In the sample material, evolutionists usually present the ad hominem arguments in the context of defending evolutionary figures from demonization and they could also be classified as tu quoque (Table 7). In fact, claims of evolutionary racism or Nazism are often rebutted by pointing to similar cases by creationists as follows: "The Bible Belt in the southern United States fought hardest to maintain slavery", "Henry Morris... has in the past read racism into his interpretation of the Bible" (TalkOrigins archive 2013b). When creationists claim that "scientists find what they expect to find", the naturalistic rebuttal ends with the $t u$ quoque "creationists find what they want to find" (TalkOrigins archive 2013f). Evolutionary proponents also utilize appeals to consequences. It has been said that humankind is on the brink for "either a marvelous future, or disaster. Ignorance [creationism] will almost certainly lead to the latter" (Young 1985). This is also an example of a false dilemma ("marvelous future-disaster"). However, fallacies are sometimes recognized in evolutionary rebuttals. For instance, the irrelevancy of ad hominem or ad consequentiam is indicated when discussing potential evolutionary racism by stating "None of this matters to the science of evolution" (TalkOrigins archive 2013b).

Table 7 Examples of fallacies in anti-creationist writings by evolutionary theory proponents

\begin{tabular}{|c|c|c|c|}
\hline Type of fallacy & Portrayal or citation & Science content & Source \\
\hline \multirow[t]{3}{*}{ Ad hominem } & $\begin{array}{l}\text { "Distorting real scientific research to further their agenda is obviously nothing new for the } \\
\text { ICR (Institute for Creation Research)..." }\end{array}$ & Yes & $\begin{array}{l}\text { Panda's Thumb } \\
\text { archive } 2013\end{array}$ \\
\hline & $\begin{array}{l}\text { "Many creationists have a literally holier-than-thou attitude. For example, they (falsely) claim } \\
\text { that believers of evolution are atheistic and evil. You cannot get any more snobbish or elitist } \\
\text { than that." }\end{array}$ & $\mathrm{No}^{1}$ & $\begin{array}{l}\text { TalkOrigins } \\
\text { archive } 2013 d\end{array}$ \\
\hline & $\begin{array}{l}\text { "All three (creationists) are open Christian apologetics, and therefore cannot seriously be } \\
\text { considered to be ideologically unbiased... None of them are qualified to comment on } \\
\text { evolution for the simple reason that their degrees are not in any of the organismal biological } \\
\text { sciences." }\end{array}$ & No & $\begin{array}{l}\text { Pigliucci } \\
\text { et al. } 2004\end{array}$ \\
\hline \multirow[t]{4}{*}{ Tu quoque } & "The Nazi Party in general rejected Darwinism and supported Christianity." & Yes & $\begin{array}{l}\text { TalkOrigins } \\
\text { archive } 2013 c\end{array}$ \\
\hline & $\begin{array}{l}\text { "Perhaps when creationists claim that scientists are operating under ulterior motives, they are } \\
\text { merely projecting how they themselves operate." }\end{array}$ & Yes & $\begin{array}{l}\text { TalkOrigins } \\
\text { archive } 2013 \mathrm{~g}\end{array}$ \\
\hline & $\begin{array}{l}\text { "When Piltdown was exposed, it stopped being used as evidence. The creationist hoaxes, } \\
\text { however, can still be found cited as if they were real. Piltdown has been over and done with } \\
\text { for decades, but the dishonesty of creationist hoaxes continues." }\end{array}$ & Yes & $\begin{array}{l}\text { TalkOrigins } \\
\text { archive 2013i }\end{array}$ \\
\hline & $\begin{array}{l}\text { "The lessons of history leave no doubt that wars, campaigns of persecution, torture, murder, } \\
\text { and all manner of atrocities are as likely to be committed in the name of God... as in his } \\
\text { absence." }\end{array}$ & Yes & Young 1985, 33 \\
\hline \multirow[t]{2}{*}{ Ad consequentiam } & $\begin{array}{l}\text { "...the closed-minded propaganda of the Creationists could also threaten our freedom } \\
\text { of inquiry." }\end{array}$ & Yes & $\begin{array}{l}\text { Young 1985, } \\
272\end{array}$ \\
\hline & $\begin{array}{l}\text { "...both groups want the country recast as a Christian fundamentalist nation. And they both } \\
\text { abhor the concept of evolution and want science redefined." }\end{array}$ & No & $\begin{array}{l}\text { Zimmerman } \\
2010\end{array}$ \\
\hline \multirow[t]{2}{*}{$\begin{array}{l}\text { Appeals to } \\
\text { authority }\end{array}$} & $\begin{array}{l}\text { "A governmental requirement for teaching intelligent design or other so-called alternatives } \\
\text { to evolution would likely be found unconstitutional..." }\end{array}$ & Yes & $\begin{array}{l}\text { TalkOrigins } \\
\text { archive } 2013 e\end{array}$ \\
\hline & "Evolution as religion has been rejected by the courts." & Yes & $\begin{array}{l}\text { TalkOrigins } \\
\text { archive } 2013 \mathrm{~h}\end{array}$ \\
\hline
\end{tabular}


Detailed refutations to creationist claims that are out of scientific context and thus fallacious could be treated as counter-fallacies. The first type is the rebuttal of a fallacy with a response that contains the same fallacy as the original claim (very often leading to tu quoque). This seems to cause a vicious circle of fallacies and counterfallacies that can eventually dominate the discussion. The other type of counter-fallacy is the ignoratio elenchi or irrelevant argumentation fallacy (van Eemeren and Grootendorst 1992). In this case, the opponent produces a detailed and carefully formulated response to a fallacious argument, such as the association of evolutionary theory to Nazism. The response (e.g., TalkOrigins archive 2013c) includes cited examples of the Nazi party being opposed to evolutionary theory, Hitler's Christian background and a well-balanced conclusion that "of course, this does not mean that Hitler's ideas were based on creationism any more than they were based on evolution. Hitler's ideas were a perversion of both religion and biology." It can certainly be useful to discuss and unravel the motivations and historical background of Nazism but, at this point, the debate has left the context of evolutionary evidence and the original fallacious ad consequentiam argument is treated as if it were relevant to the discussion of evolutionary proof.

\section{Prevalence of fallacies}

All above-mentioned fallacies were present in the sampled texts with the highest prevalence being $100 \%$ for tu quoque in ID/OEC, $88 \%$ for appeals to authority in YEC and 56\% for ad hominem and tu quoque in pro- evolutionary texts (Figure 1). The prevalence of direct ad hominem did not differ between the classifications (YEC, ID/OEC or pro-evolutionary); regarding most of the other fallacies, the prevalence was lower in proevolutionary texts. The prevalence of ad ridiculum was higher in ID/OEC compared to the other text types.

\section{Discussion and conclusions}

The creationist-evolutionist discussion focuses on scientific dispute on the evidence regarding evolutionary theory but, in reality, creationist texts contain numerous fallacious arguments not directly if at all related to the issue of science. A large part of scientific rebuttals concentrates on these fallacious claims and eventually leads to counter-fallacies. Ad hominem and tu quoque arguments were especially prevalent in all forms of creationist and pro-evolutionary texts. However, it must be emphasized that the analyzed texts were not selected randomly but based on visibility and impact. Thus, the results on the prevalence of fallacies in the creationistevolutionist debate do not necessarily reflect a general pattern. Still, we can tentatively surmise that most of the examined types of fallacies commonly occur in the analyzed forms of creationism. Creationist claims are often based on criticizing evolutionary theory by using selected data derived from scientists. In addition, also opinions and popularized books of evolutionary proponents are equivocated to represent the actual evolutionary theory. The use of these, often out-of-context pieces of data, leads to rebuttals and it is often these refutations that contain the counter-fallacies of evolutionary proponents. Still, participation in the debate in a rational manner would

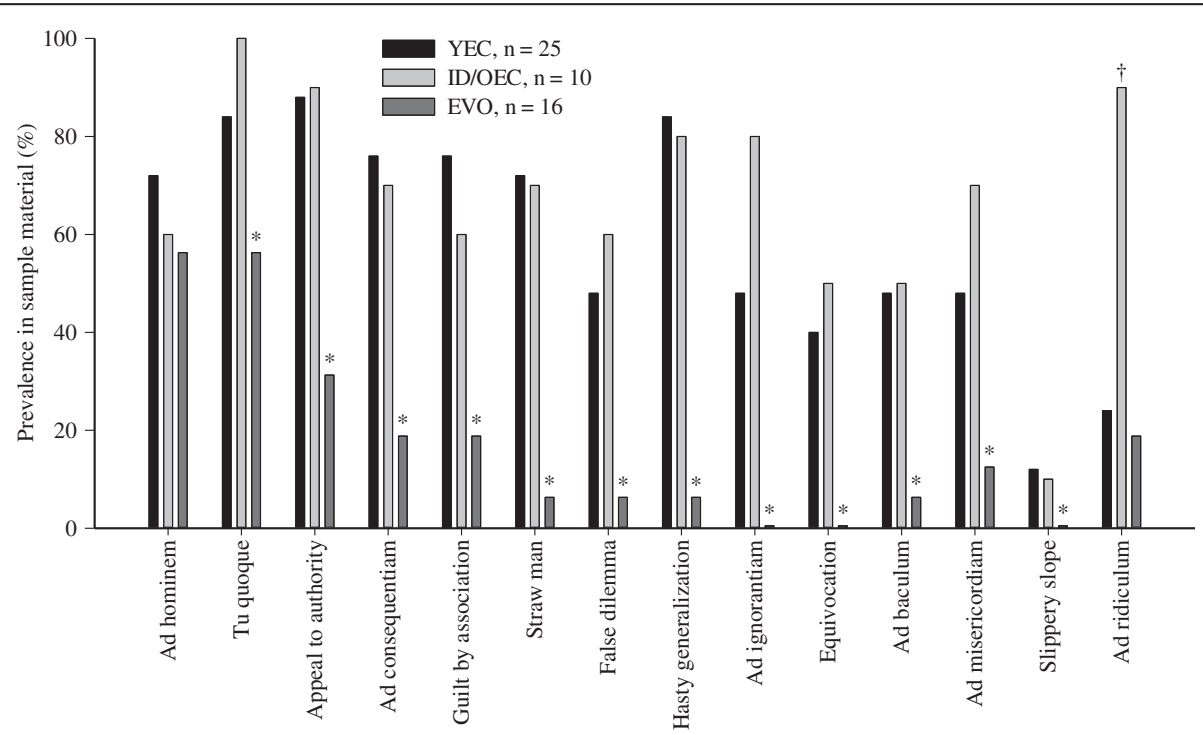

Figure 1 Prevalences (\%) of the analyzed fallacies in texts related to the creationist-evolutionist debate. YEC = young earth creationism, ID/OEC = intelligent design/old earth creationism, EVO = pro-evolutionary texts. * = Difference between EVO and the other text types ( $p<0.05$; $x^{2}$ test, Fisher's exact test), $\dagger=$ difference between ID/OEC and the other text types $(p<0.001$; Fisher's exact test). 
require both parties to avoid irrelevant fallacies whenever possible.

Furthermore, creationist fallacies are international. The sampled Finnish texts consisted largely of paraphrases and translated citations of English-language creationist texts and used the same tu quoque quotes (often out of context) as international creationist sites (Puolimatka 2009, 2010; Table 3). The general pattern of creationist "scientific evidence" is to select and re-interpret a piece of data from main-stream science and publish it in a creationist journal with a reference to the actual study (Carter 2010). In the Finnish texts, the only remaining reference is often to the creationist paraphrasing, which is presented as the "proof", for instance in the above-mentioned debate on the alleged human-chimpanzee genetic difference of 30\% (e.g., Reinikainen 2011).

Within the context of the present study, the observed fallacies are not relevant when considering scientific evidence against evolution. Still, for instance, in legal settings ad hominem (or guilt by association) could be a valid argument when using character witnesses to assess the reliability of a defendant (Yap 2013). In fact, creationists have employed this strategy by using the narrative of evolutionary theory or "Darwinism" as the accused party and presenting unpleasant moral associations between (proponents of) evolution and various atrocities. Johnson (1993) uses this by discussing evolutionary theory almost as a case to be judged in a legal court. Johnson states that his aim was "to examine the scientific evidence on its own terms, being careful to distinguish the evidence itself from any religious or philosophical bias..." However, in the same work he utilizes appeals to authority, tu quoque and ad consequentiam with references to Stalinism, Marxism and Nazism. While these arguments can be relevant in court (Yap 2013), this strategy is fallacious in evolutionary debate, because the credibility of the scientist is ultimately quite irrelevant: the claim can always be confirmed by the original data and/or repeating the experiments. Still, it must be acknowledged that it is virtually impossible to employ source criticism on all occasions and some data may have to be considered reliable after peer-review without examining the original evidence. Discussion about the integrity of scientists can certainly be useful and not fallacious in the context of reliability even if it did not provide actual proof on a theory.

The examples of ad hominem and ad consequentiam as well as the appeals to authority (such as court cases) in pro-evolutionary writings should also be scrutinized regarding their context. It can be argued that these examples would not be fallacious if their aim was to draw the attention of the audience to possible lack of expertise and not only to reject the opposing viewpoint. In a similar manner, the ad consequentiam stating that creationism leads to disruption of scientific research (e.g., Young
1985) would not necessarily be fallacious in the context of discussion about society and education. However, to avoid counter-fallacies, it would be prudent to express clearly the actual aim stating, for instance, that the argument is not about the scientific evidence for or against creationism (which would be discussed elsewhere) but about the implications (educational, theological, sociological, etc.) creationism would have if it were adopted as the theory on the appearance of life and biodiversity on the earth. The theological arguments of evolutionary proponents and the dismissal of these by the tu quoque arguments of creationists also merit further consideration. It may seem plausible that evolutionists themselves use a fallacy when introducing religion in evolutionary debate. However, in these cases, evolutionary proponents refer to the potential theological implications of creationism, i.e., what the characteristics of a deity or an intelligent designer would be, if YEC or ID were true. For instance, Dawkins (1986) discussed the skull form of the flounder as something which would be hard to explain if ID was correct and the form had been designed by a supernatural entity. In the context of an omnipotent, omniscient and perfectly good God, the arguments of imperfection and suffering are quite legitimate as argued also by Boudry and Leuridan (2011). Thus, the creationist tu quoque remains a fallacy, as evolutionary biologists have the right to participate in the discourse over ID. Of course, the validity and rationality of their theological claims can be assessed within that frame.

An explanation to the creationist hasty rejection of a method or theory based on a small number of divergent data can perhaps be found in the (YEC) paradigm of literal interpretation of the Bible. In the context of argumentation theory, one proven error in a text would not automatically mean that any other part of the same text would be erroneous. Thus, one error in the Bible would not automatically undermine any other part of it. However, for YEC, one error in the Bible would mean that the certainty of all the other parts would be jeopardized: it would be impossible to abandon the historicity and divine authority of the Genesis without a collapse in the authority of the whole Bible (Reinikainen 1991, 2011). The same approach seems to be used when creationist writings criticize evidence for evolution: alleged isolated inaccuracies can be taken as detrimental for a whole theory or method (e.g., radiometric dating, Swenson 2001). Yet, in the disciplines of natural sciences, there never was any certainty to begin with. The theories are based on (statistical) interpretation of evidence and not taken as literal truths. The transfer of the paradigm of personal belief or YEC/ID/OEC dogma with the requirement of inerrancy to natural sciences where the possibility of errors is always present yields fallacious arguments that do not strengthen the creationist case. 
Fallacious argumentation is not irrelevant in the context it is presented in. In fact, the vicious circle of fallacies and counter-fallacies can make the science seem irrelevant and the character of the scientists, their opponents and the real or imagined moral implications of science the most relevant part of the discussion. The decades-long debate with the same fallacies being constantly repeated ad nauseam could be an indication of this. When presented in a context of "scientific creationism" (i.e., modern YEC) or ID/OEC, the observed fallacies could be effective tools to persuade an audience (Yap 2013). We tentatively divide the potential audience into three groups as follows: i) those with existing creationist convictions or biases, ii) the undecided and $\mathrm{iii}$ ) those with pro-evolutionary convictions or biases. The first group could react as suggested by Yap (2013), where the audience with pre-existing biases evaluates the arguments based on fallacies. This can "fix beliefs" or "generate false or unfounded beliefs" (Fogelin and Duggan 1987). In fact, it has been suggested that the appeal and persistence of the creationists' ideas do not depend on the "science content" of YEC or ID/OEC but on their cultural, sociological and cognitive dispositions (Boudry et al. 2010a). There could also be a connection between religiosity and the effects of these biases (Blancke et al. 2012), especially when considering that creationism is based on the literal interpretation of the Bible.

In the case of an evolutionary proponent, the reaction to repeated fallacies could be that of irritation (possibly subconscious if the fallacy and its context are not recognized) and lead to counter-fallacies as presented above. Examples of the latter reaction are available in proevolutionary Internet sites that can include the recognition of fallacies but, at the same time, the rebuttals of fallacious claims also include tu quoque (e.g., EvoWiki 2013) and disqualification of creationists as opponents (Pigliucci et al. 2004). This strategy has apparently not been able to reduce the widespread utilization of scientifically irrelevant fallacies in creationist (or evolutionist) texts, and also previous reports have suggested that natural scientists should concentrate on discussing ID claims based on purely evidential grounds (Boudry et al. 2010b, 2012). Our results strengthen the notion that the constant use of fallacies in persuasion can be a factor in the continuing success of creationism despite of scientific counter-evidence. Based on the present analysis, we present here an alternative way to approach the fallacies in creationism.

1. Discuss the scientific claims with arguments that are valid for natural sciences.

2. Recognize fallacies and determine if the fallacious arguments are relevant for the science content.

3. If the fallacies are irrelevant for science, analyze the context of the fallacy within the book, journal article or Internet site. Is the science content presented together with fallacies? Discuss the fallacy as a potential tool for creating erroneous beliefs for the audience.

4. Avoid counter-fallacies, especially ad hominem in your rebuttal. If you feel it is necessary to refute ad hominem and ad consequentiam claims with a detailed counter-fallacy, acknowledge the irrelevance of the issue in the scientific validity of evolution. If the argument is relevant and not fallacious regarding, e.g., education and social issue, acknowledge this. Remember the fallacist's fallacy (Curtis 2001): a claim is not wrong simply because it is defended by a fallacious argument.

5. When discussing the theological implications of, for example, ID, remember to clarify that the context is not evolutionary theory but the potential absence of it, i.e., creationism.

While the suggested approach is tentative, it should not cause anxiety in either party of the creationist-evolutionist debate. Obviously, the scientific rebuttals against YEC and ID/OEC claims would remain detailed and well-formulated even without the concomitant counter-fallacies. The same would ultimately benefit creationists if their goal is to let the evidence decide and let the theory that explains best the biodiversity of the natural world prevail.

\section{Abbreviations \\ ID: Intelligent design; OEC: Old earth creationism; YEC: Young earth creationism.}

\section{Competing interests}

The authors declare that they have no competing interests.

\section{Authors' contributions}

PN designed the study, collected the sample material and conducted the textual analyses. AMM commented on the analyses. PN wrote the first draft of the text and the final form was accomplished by both authors. Both authors read and approved the final manuscript.

\section{Acknowledgements}

The authors sincerely thank Dr. Maarten Boudry, Doc. Esko Ryökäs and MA Ulla Nieminen for their critical comments on the manuscript.

Received: 15 August 2013 Accepted: 17 March 2014

Published online: 24 April 2014

\section{References}

Aikin, SF, \& Casey, J. (2011). Straw men, weak men, and hollow men. Argumentation, 25, 87-105.

Behe, MJ. (2007). The Edge of Evolution. The Search for the Limits of Darwinism. New York: Free Press.

Bergman, J. (1999). Darwinism and Nazi race holocaust. CEN Technical Journal, $13,101-111$

Bergman, J. (2004). Was Charles Darwin psychotic? A study of his mental health. Impact, \#367.

Bergman, J. (2005). Darwin's passion for hunting and killing. Impact, \#383.

Bergman, J. (2012). Anders Breivik—social Darwinism leads to mass murder. Journal of Creation, 26, 48-53. 
Blancke, S, De Smedt, J, De Cruz, H, Boudry, M, \& Braeckman, J. (2012). The implications of the cognitive sciences for the relation between religion and science education: the case of evolutionary theory. Science \& Education, 21, 1167-1184

Boudry, M, \& Leuridan, B. (2011). Where the design argument goes wrong: auxiliary assumptions and unification. Philosophy of Science, 78, 558-578.

Boudry, M, Blancke, S, \& Braeckman, J. (2010a). How not to attack intelligent design creationism: philosophical misconceptions about methodological naturalism. Foundations of Science, 15, 227-244.

Boudry, M, Blancke, S, \& Braeckman, J. (2010b). Irreducible incoherence and intelligent design: a look into the conceptual toolbox of a pseudoscience. Quarterly Review of Biology, 85, 473-482.

Boudry, M, Blancke, S, \& Braeckman, J. (2012). Grist to the mill of antievolutionism: the failed strategy of ruling out the supernatural out of science by philosophical fiat. Science \& Education, 21, 1151-1165.

Brace, RA. (2004). The Bible and Evolution. I was asked for, "information on evolution", my conclusion: surely evolution is the greatest 'act of faith' of all time! UK Apologetics. http://www.ukapologetics.net/1evolutionfaith.htm. Accessed 24 January 2013.

Brace, RA. (2006). The Utter Failure of the $19^{\text {th }} / 20^{\text {th }}$ Century Atheistic Icons. Charles Darwin (1809-1882). It's time for the truth to be told... UK Apologetics. http://www.ukapologetics.net/8DARWIN.htm. Accessed 22 January 2013.

Brink, DO. (2007). The autonomy of ethics. In M Martin (Ed.), The Cambridge Companion to Atheism (pp. 149-165). Cambridge: Cambridge University Press.

Buchanan, S. (2010). Assessing Limits to Evolution and Natural Selection: Reviews of Michael Behe's "Edge of Evolution" and John Sanford's "Genetic Entropy". http://letterstocreationists.wordpress.com/stan-4/. Accessed 10 February 2013.

Buchanan, S. (2012). Gorilla, Orangutang, Chimp and Human Genomes: Population Genetics and Intelligent Design. http://letterstocreationists.wordpress.com/ 2012/03/17/gorilla-orangutan-chimp-and-human-genomes-populationgenetics-and-intelligent-design/. Accessed 15 January 2013.

Carrier, R. (2004). Antony Flew Considers God... Sort of. http://www.infidels.org/ kiosk/article369.html. Accessed 17 February 2013.

Carter, RW. (2010). The Chimpanzee Y Chromosome is Radically Different from Human. Creation Ministries International. http://creation.com/chimp-ychromosome. Accessed 1 February 2013.

Catchpoole, D, \& Sarfati, J. (2006). Schweitzer's Dangerous Discovery. Creation Ministries International. http://creation.com/schweitzers-dangerous-discovery. Accessed 25 January 2013

Curtis, GN. (2001). Fallacy Files. http://www.fallacyfiles.org/aboutgnc.html. Accessed 10 December 2012.

Darwin, C. (1859). The Origin of Species by means of Natural Selection or the Preservation of Favoured Races in the Struggle for Life (1st ed.). http://www. gutenberg.org/files/1228/1228-h/1228-h.htm. Accessed 2 January 2013.

Data360.org. (2006). Belief in Evolution - \% of Population. Data360. http://www. data360.org/dsg.aspx?Data_Set_Group_Id=507. Accessed 17 February 2013.

Davis, P, \& Kenyon, DH (Eds.). (1998). Of Pandas and People. The Central Question of Biological Origins (2nd ed.). Dallas: Haughton.

Dawkins, R. (1986). The Blind Watchmaker. New York: W. W. Norton \& Company.

Dawkins, R. (1989a). The Selfish Gene. Oxford: Oxford University Press.

Dawkins, R. (1989b). Review of blueprints: solving the mystery of evolution. New York Times, April, 9, 1989

Deming, D. (2008). Design, science and naturalism. Earth-Science Reviews, $90,49-70$.

Dowden, B. (2010). Internet Encyclopedia of Philosophy. Fallacies. http://www.iep. utm.edu/fallacy/. Accessed 13 February 2013.

Doyle, S. (2007). Feathery flight of fancy: alleged 'protofeathers' fail under close scrutiny. Journal of Creation, 21, 11-12.

Durrett, R, \& Schmidt, D. (2008). Waiting for two mutations: with applications to regulatory sequence evolution and the limits of Darwinian evolution. Genetics, 180, 1501-1509.

EvoWiki. (2013). Evolution is Racist. EvoWiki. A RationalWiki Foundation Project. http://evolutionwiki.org/wiki/Evolution_is_racist. Accessed 5 March 2013.

Fogelin, RJ, \& Duggan, TJ. (1987). Fallacies. Argumentation, 1, 255-262.

Gilbert, W. (1986). Origin of life: The RNA world. Nature, 319, 618.

Grigg, R. (2005). Eugenics... death of the defenceless. The legacy of Darwin's cousin Galton. Creation, 28, 18-22.

Grigg, R. (2010). Herbert Spencer. The father of social Darwinism. Creation, $32,52-54$.

Harker, BR. (2011). Science and rationality. Journal of Creation, 25, 121-127.
Harris, WS, \& Calvert, JH. (2003). Intelligent design. The scientific alternative to evolution. National Catholic Bioethics Quarterly, Autumn 2003, 531-561.

Hodge, B. (2007). Finland School Shootings: The Sad Evolution Connection. Answers in Genesis. http://www.answersingenesis.org/articles/2007/11/08/finland-fruitsof-humanism. Accessed 2 February 2013.

Hughes, JF, Skaletsky, H, Pyntikova, T, Graves, TA, van Daalen, SKM, Minx, PJ, Fulton, RS, McGrath, SD, Locke, DP, Friedman, C, Trask, BJ, Mardis, ER, Warren, WC, Repping, S, Rozen, S, Wilson, RK, \& Page, DC. (2010). Chimpanzee and human $Y$ chromosomes are remarkably divergent in structure and gene content. Nature, 463, 536-539.

International Theological Commission. (2004). Communion and Stewardship: Human Persons Created in the Image of God. http://www.vatican.va/ roman_curia/congregations/cfaith/cti_documents/rc_con_cfaith_doc_ 20040723_communion-stewardship_en.html. Accessed 2 February 2013.

Isaak, M (Ed.). (2006). Index to Creationist Claims. The TalkOrigins Archive. http:// www.talkorigins.org/indexcc/list.html. Accessed 14 February 2013.

Johnson, PE. (1993). Darwin on Trial. Talebooks. http://talebooks.com/ebooks/291. pdf. Accessed 2 January 2013.

Johnson, PE. (1995). Reason in the Balance. The Case against Naturalism in Science, Law \& Education. Downers Grove: InterVarsity Press.

Jovičić, T. (2004). Authority-based argumentative strategies: a model for their evaluation. Argumentation, 18, 1-24.

King James Bible. (2013). Online Edition. http://www.kingjamesbibleonline.org/. Accessed 11 November 2013.

Leisola, M. (2012). Preface. In K Pälikkö (Ed.), From the Beginning to the Last Days (pp. 6-8). Helsinki: KP-art. In Finnish.

Luskin, C. (2009). The constitutionality and pedagogical benefits of teaching evolution scientifically. University of St. Thomas Journal of Law \& Public Policy, N, 204-277.

Luskin, C, \& Gage, LP. (2008). A reply to Francis Collins's Darwinian arguments for common ancestry of apes and humans. In HW House (Ed.), Intelligent Design 101. Leading Experts Explain the Key Issues (pp. 215-235). Grand Rapids: Kregel Publication.

Mackie, JL. (1982). The Miracle of Theism. Arguments for and against the Existence of God. Oxford: Clarendon Press.

McGrath, AE. (2010). Science and Religion. A New Introduction (2nd ed.). Chichester: John Wiley \& Sons.

Morris, HM. (1972). The Remarkable Birth of Planet Earth. Minneapolis: Bethany Fellowship.

Morris, HM. (2001). Evolution is religion-not science. Impact, \#332.

Morris, JD. (2013). Just How Well Proven is Evolution? Institute of Creation Research. http://icr.org/article/2605/. Accessed 28 January 2013.

Numbers, RL. (1982). Creationism in $20^{\text {th }}$-century America. Science, 218, 538-544.

Numbers, RL. (2011). Clarifying creationism: Five common myths. History and Philosophy of the Life Sciences, 33, 129-139.

Panda's Thumb. (2013). http://www.pandasthumb.org/. Accessed 3 February 2013.

Panda's Thumb archive. (2013). Creationists and Y Chromosomes. http://pandasthumb.org/archives/2010/10/creationists-an-1.html. Accessed 2 January 2013.

Pennock, RT. (2003). Creationism and intelligent design. Annual Review of Genomics and Human Genetics, 4, 143-163.

Pieret, J. (2006). The Quote Mining Project or, Lies, Damned Lies, and Quote Mines. http://www.talkorigins.org/faqs/quotes/mine/project.html. Accessed 31 January 2013.

Pigliucci, M, Banta, J, Bossu, C, Crouse, P, Dexter, T, Hansknecht, K, \& Muth, N. (2004). The alleged fallacies of evolutionary theory. Philosophy Now, 46. http://philosophynow.org/issues/46/ The_Alleged_Fallacies_of_Evolutionary_Theory. Accessed 4 March 2013.

Popper, K. (1978). Natural selection and the emergence of mind. Dialectica, $32,339-355$.

Puolimatka, T. (2009). Faith, Science and Evolution (2nd ed.). Helsinki: Uusi Tie. In Finnish.

Puolimatka, T. (2010). A Test for Openness in Science Discussion. Helsinki: Uusi Tie. In Finnish.

Purves, WK, Sadava, D, Orians, GH, \& Heller, HC. (2006). Life. The Science of Biology (7th ed.). Gordonsville: W.H. Freeman and Company.

Reinikainen, P. (1991). The Forgotten Genesis. Helsinki: Uusi Tie. In Finnish.

Reinikainen, P. (2003). The Enigma of the Dinosaurs and the Bible. Jyväskylä: Kuva ja Sana. In Finnish.

Reinikainen, P. (2011). Darwin or Intelligent Design. Helsinki: Uusi Tie. In Finnish. 
Reinikainen, P. (2013a). Evolution or Creation? http://www.pekkareinikainen.info/fi/ index.php?option=com_content\&task=view\&id=25\&ltemid=27. Accessed 5 February 2013. In Finnish.

Reinikainen, P. (2013b). Lower than Angels. http://www.pekkareinikainen.info/fi/ index.php?option=com_content\&task=view\&id=24\&ltemid=27. Accessed 5 February 2013. In Finnish.

Sahlane, A. (2012). Argumentation and fallacy in the justification of the 2003 war on Iraq. Argumentation, 26, 459-488.

Sarfati, J. (2007). Reinforcing the Darwin-Hitler Connection and Correcting Misinformation about Slavery and Racism. Creation Ministries International. http://creation.com/the-charles-darwin-adolf-hitler-connexion-correctingmisinformation-re-slavery-racism. Accessed 2 February 2013.

Schweitzer, MH, Marshall, M, Carron, K, Bohle, DS, Busse, SC, Arnold, EV, Barnard, D, Horner, JR, \& Starkey, JR. (1997). Heme compounds in dinosaur trabecular bone. Proceedings of the National Academy of Sciences, 94, 6291-6296.

Scott, EC. (1997). Antievolution and creationism in the United States. Annual Review of Anthropology, 26, 263-289.

Shermer, M. (2002). Why People Believe Weird Thing. Pseudoscience, Superstition, and other Confusions of our Time. New York: Henry Holt and Company.

Swenson, K. (2001). Radio-Dating in Rubble. The Lava Dome at Mount St Helens Debunks Dating Methods. Answers in Genesis. http://www.answersingenesis. org/articles/cm/v23/n3/radiodating. Accessed 2 February 2013.

TalkOrigins archive. (2013a). Claim CB030. http://www.talkorigins.org/indexcc/CB/ CB030.html. Accessed 15 January 2013.

TalkOrigins archive. (2013b). Claim CA005. http://www.talkorigins.org/indexcc/CA CA005.html. Accessed 15 January 2013.

TalkOrigins archive. (2013c). Claim CA006.1. http://www.talkorigins.org/indexcc/ CA/CA006 1.html. Accessed 15 January 2013.

TalkOrigins archive. (2013d). Claim CA012. http://www.talkorigins.org/indexcc/CA/ CA012.html. Accessed 15 January 2013.

TalkOrigins archive. (2013e). Claim CA041.1. http://www.talkorigins.org/indexcc/ CA/CA041_1.html. Accessed 15 January 2013.

TalkOrigins archive. (2013f). Claim CA310. http://www.talkorigins.org/indexcc/CA/ CA310.html. Accessed 15 January 2013.

TalkOrigins archive. (2013g). Claim CA321. http://www.talkorigins.org/indexcc/CA/ CA321.html. Accessed 15 January 2013.

TalkOrigins archive. (2013h). Claim CA610. http://www.talkorigins.org/indexcc/CA CA610.html. Accessed 15 January 2013.

TalkOrigins archive. (2013i). Claim CCO01. http://www.talkorigins.org/indexcc/CC/ CC001.html. Accessed 15 January 2013.

Todd, SC. (1999). A view from Kansas on that evolution debate. Nature, 401, 423

Tomić, T. (2013). False dilemma: a systematic exposition. Argumentation, 27, 347-368.

van Eemeren, FH, \& Grootendorst, R. (1992). Argumentation, Communication, and Fallacies. A Pragma-Dialectical Perspective. New York: Routledge.

Wallace, AR. (1858). On the tendency of varieties to depart indefinitely from the original type. Journal of the Proceedings of the Linnean Society of London, Zoology, 3, 53-62

Walton, D. (1999a). Rethinking the fallacy of hasty generalization. Argumentation, 13, 161-182.

Walton, D. (1999b). The appeal to ignorance, or argumentum ad ignorantiam. Argumentation, 13, 367-377.

Walton, DN. (2006). Poisoning the well. Argumentation, 20, 273-307.

Wieland, C. (1997). Sensational dinosaur blood report! Creation, 19, 42-43.

Wiens, RC. (2002). Radiometric Dating. A Christian Perspective. The American Scientific Association. http://www.asa3.org/ASA/resources/Wiens2002.pdf. Accessed 11 November 2013

Woods, J. (1998). Argumentum ad baculum. Argumentation, 12, 493-504.

Yahya, H. (2006). Atlas of Creation (Vol. 1). Ankara: Global Publishing.

Yap, A. (2013). Ad hominem fallacies, bias, and testimony. Argumentation, $27,97-109$

Young, W. (1985). Fallacies of Creationism. Calgary: Detselig Enterprises.

Zimmerman, M. (2010). The danger of ignoring creationism. Blog. Huffington Post, 15 April 2010

doi:10.1186/s12052-014-0011-6

Cite this article as: Nieminen and Mustonen: Argumentation and

fallacies in creationist writings against evolutionary theory. Evolution: Education and Outreach 2014 7:11.

\section{Submit your manuscript to a SpringerOpen ${ }^{\circ}$ journal and benefit from:}

- Convenient online submission

- Rigorous peer review

- Immediate publication on acceptance

- Open access: articles freely available online

- High visibility within the field

- Retaining the copyright to your article

Submit your next manuscript at $\gg$ springeropen.com 